\title{
КОНСТРУКТИВНЫЙ ПРОТЕСТ В КОНСТИТУЦИОННОМ ПРАВЕ: ИДЕАЛИЗИРОВАННЫЙ МИФ ИЛИ ПОТЕНЦИАЛЬНАЯ РЕАЛЬНОСТЬ?
}

\begin{abstract}
Аннотация: Настоящая статья делает попытку определить понятие и содержание категории "конструктивный протест» как механизма реализации права на участие в управлении делами государства, гарантированного ст. 32 Конституции России. Согласно нашей концепции протест должен быть направлен на достижение конечного результата: на выдвижение конкретного требования к органам публичной власти или же варианта решения конкретной публично-правовой проблемы. Автор рассматривает как легитимный протест только мирные акции, считая любые нарушения общественного и правового порядка в ходе выражения несогласия неправомерными и преследуемыми по закону. Мы пришли к выводу о том, что санкции за нарушение процедуры выражения протеста не могут быть единственным средством, стимулирующим граждан к выражению конструктивного протеста. Задача повышения правовой культуры граждан является одной из наиболее важных проблем на пути оптимизации диалога между государством и гражданским обществом.

Ключевые слова: конструктивный протест, политические права, участие в управлении, собрания граждан, правовая культура, злоупотребление правом, петиции, выражение несогласия, Конституция РФ, демократическое государство.

DOI: $10.7256 / 1729-5920.2014 .5 .9948$
\end{abstract}

\section{Введение}

В начале 2013 г. граждане г. Санкт Петербурга проводили систематические акции протеста против закрытия Городской клинической больницы № 31, помещения которой планировалось отвести под элитный госпиталь для судей высших судебных инстанций. Эта больница оказывает помощь пациентам с онкологическим диагнозом, в том числе детям. Понимая важность этого медицинского учреждения, граждане выдвинули требования к органам публичной власти о недопустимости закрытия ГКБ № 31. Протест выражался в форме петиций, демонстраций, обращений в СМИ и т.д. В итоге государство прислушалось к протестующим и приняло решение о продолжении деятельности этой больницы.
В середине 2013 г. активисты международного движения «Гринпис» попытались повесить плакат на платформе «Приразломная» в Печорском море, принадлежащей корпорации «Газпром». При этом их судно Arctic Sunrise приблизилось к платформе на опасное расстояние. Они нарушили целый ряд правовых норм. В итоге государство инициировало против них уголовное расследование по статье «пиратство».

Оба этих инцидента выражали протест против действий органов публичной власти, однако они привели к противоположным результатам. В обоих случаях протестанты были уверены в том, что они реализуют свое право на выражение несогласия с действиями государственных органов. Однако «конструктивным протестом» мы можем обозначить только первую ситуацию.

(C) Риэккинен Мария Александровна

* Доктор социологических наук, исследователь - профессор Åbo Akademi University, Финляндия;

Тюменский государственный университет

[mpimanov@abo.fi]

Gezeliusgatan, 2; Abo Akademi, 20500 Turku, Finland. 
Применение санкций за неконструктивные протесты - это часть нормальной правоохранительной деятельности государства, которое обязано наказывать виновных за нарушение закона. Споры относительно неправомерности таких санкций неоднократно рассматривались и на международном уровне. К примеру, в нескольких делах против Франции о нарушении права на участие в управлении публичными делами заявители добросовестно заблуждались относительно правомерности сожжения ими чужого урожая генномодифицированной кукурузы. Сжигая урожай, заявители верили, что выражают таким образом свое мнение против экспериментов с генномодифицированными продуктами. Поскольку заявители допустили явное нарушение закона, запрещающего уничтожение или повреждение чужого имущества, заявления признаны Комитетом ООН по правам человека неприемлемыми 1 .

Поскольку исследования законных пределов реализации права на протест не теряют актуальности, данная статья рассматривает категорию конструктивного протеста в конституционном праве, ее содержание и условия реализации.

\section{Категория конструктивного протеста в конституционном праве}

C нашей точки зрения, протест не только отдельная форма коллективной реализации права на собрание и объединение, а правовой механизм выражения несогласия с решениями и действиями/бездействием органов публичной власти. Согласно нашему подходу выражение несогласия с политическим курсом государства может быть реализовано как посредством коллективной реализации права на свободу собраний, так и через индивидуальное использование целого ряда прав и свобод. Протест может быть выражен в виде индивидуального/коллективного обращения в органы публичной власти; объявления в средствах массовой информации; создания конкретного объединения граждан; выступления на публичных слушаниях и т.д. При этом протест представляет собой целый правовой механизм, акти-

Комитет ООН по правам человека, Brun v. France, Communication No. 1453/2006, 18 October, 2006, UN Doc. CCPR/C/88/D/1453/2006, Inadmissible ; Ms. Nicole Beydon and 19 other members of the association «DIH Mouvement de protestation civique» v. France, Communication No. 1400/2005, 31 October, 2005, UN Doc. CCPR/C/85/D/1400/2005, Inadmissible. визирующий в различных комбинациях право на свободу слова, собрания, объединения и процедуру петиций и публичных слушаний. Конструктивный протест как механизм выражения несогласия с политическим курсом государства представляет собой реализацию права на участие в управлении делами государства, гарантированного ст. 21 Всеобщей декларации прав и свобод человека, ст. 25 Международного пакта о гражданских и политических правах, положений целого ряда региональных договоров по правам человека и ст. 32 Конституции РФ.

Термин «конструктивный протест» не входит в понятийно-категориальный аппарат науки конституционного права. Категория конструктивного протеста шире по объему, чем институт публичных мероприятий, и при этом намного специфичнее в силу обладания наиболее важным квалифицирующим признаком, а именно нацеленностью на достижение определенного результата (будь это конкретное требование к органам публичной власти или же вариант решения конкретной публично-правовой проблемы).

Термин «конструктивный протест» используется в основном в литературе по социологии и политологии. К примеру, С.И. Григорьев в своей работе, посвященной исследованию вопросов социальной культуры, упоминает о существовании конструктивного протеста говоря о современных социальных движения ${ }^{2}$. В литературе по политологии наиболее известное употребление термина «конструктивный протест» связывается с именем Джозефра Гримонда - британского политика, возглавлявшего Либеральную партию с 1956 по 1967 гг. Выступая с речью перед либеральной ассамблеей в городе Саузпорт в 1957 г., Гримонд призвал либералистов к «конструктивному протесту против консерватизма», подчеркивая при этом такие характеристики конструктивного протеста, как уравновешенность, разумность и честность ${ }^{3}$.

В российском конституционно-правовом поле инициатива исследования протеста, затрагивающего и вопросы конструктивного протеста, принадлежит профрессору С.А. Авакьяну. Именно он отметил малую степень исследованности вопроса о том, при каких условиях протестное поведение может быть кон-

\footnotetext{
2 Григорьев С.И. Социальная культура: поиск новых концептуальных оснований анализа и путей развития в России // Избр. статьи 1980-90-х гг. Барнаул, 1999. с. 126.

Foote G. Republican Transformation of Modern British Policies. Basingstoke : Palgrave Macmillan, 2005. P. 93.
} 
сультативной фоормой народовластия 4 . Позднее он опубликовал схему ответа на вопрос о том, при каких условиях протест может быть эфрфективным выражением мнения граждан по поводу политических решений. В статье о демократии протестных отношений С.А. Авакьян разграничил эмоциональное выражение недовольства по отношению к органам публичной власти и рациональное высказывание критики в их адрес 5 .

На уровне международной науки различие между рациональным, взвешенным и иррациональным, эмоциональным поведением во время принятия решений было предложено Дж. Эльстером, который развивал идеи Ю. Хабермаса о совещательной демократии. Согласно теории рационального выбора, разработанной Эльстером, только рациональное поведение приводит к достижению согласия между всеми сторонами, участвующими в процессе принятия решений ${ }^{6}$.

Современные теории демократии и прав человека все чаще упоминают о протесте в его конструктивном проявлении, которое описывается как «разумное» выражение несогласия с политическим курсом государства. «Разумное» выражение протеста предполагает, во-первых, мирный способ выражения несогласия в рамках установленных законом процедур, а вовторых, выдвижение «разумных» требований ${ }^{7}$.

\section{«Разумные» граждане как ключевая составляющая реализации механизма конструктивного протеста}

В контексте современных российских правовых реалий конструктивный протест ограничен несколькими фракторами.

«Разумные» граждане как категория. Существование идеализированной категории «разумных» граждан, о которых пишут ученые, занимающиеся вопросами совещатель-

\footnotetext{
Например: Авакьян С.А. Публичная власть: конституционно-правовые аспекты // Вестник Тюменского гос. ун-та. 2009. № 2. С. 7-8.

Авакьян С.А. Демократия протестных отношений: конституционно-правовое измерение // Конституционное и муниципальное право. 2012. № 1.

6 Elster Jon. Deliberative Democracy. Cambridge : Cambridge University Press, 1998 ; Idem. Reason and Rationality. Princeton : Princeton University Press, 2009.

Например: Elster Jon. Deliberative Democracy ; Idem. Reason and Rationality ; Habermas Jurgen. Contributions to a Discourse Theory of Law and Democracy. Cambridge : the MIT Press, 1996. P. 170, 305-306 ; Wheatley Steven. The Democratic Legitimacy of International Law. Hart Publishing, 2010.
}

ной демократии, находится под сомнением как таковое, и не только в России. Обратимся к участию граждан в принятии решений по вопросам социального обеспечения в России. Мы вынуждены констатировать, что большое количество граждан нуждается в усиленных социально-экономических гарантиях со стороны государства. По данным Федеральной службы государственной статистики , только в 2012 г. 12,1 \% официального населения России находилось за чертой бедности ${ }^{8}$. Было бы наивным полагать, что большинство граждан из этой категории способны на активный и мирный диалог как с властью, так и с другими гражданами на уровне абстрактной политической проблематизации насущных проблем. Такие объективные факторы, как отсутствие правовой грамотности и невысокий уровень юридической культуры, - далеко не единственные причины политической пассивности. Следует учитывать и человеческий фактор, способный повлиять на политическую пассивность в зависимости от субъективных характеристик - низкого уровня жизни или ряда серьезных нерешенных социальных проблем (например, личностные характеристики граждан, злоупотребление алкоголем могут предопределять отсутствие интереса к политической активности) ${ }^{9}$. Кроме того, на формирование позиции разумной гражданственности оказывают влияние и институциональные причины, такие как отсутствие слаженной системы общественных движений ${ }^{10}$. Предположим, что если отдельные представители этих $12,1 \%$ населения примут решение активно выступать против поднятия тарифов на газ или электричество, то в отсутствие организованного общественного движения единомышленников такие выступления рискуют перерасти в акты гражданского неповиновения, преследуемые по закону.

\footnotetext{
Официальная страница ФСГС в сети Интернет. URL: http://www.gks.ru/free_doc/new_site/population/urov/ urov_52.htm.

9 Например: Варламова Н.В. Человеческий фактор в развитии социалистического самоуправления народа // Политическая система: вопросы демократии и самоуправления. М. : ИГПАН, 1988 ; Клюев А.В. Политическая активность и формирование гармонично развитой, общественно активной личности. Л. : Изд-во Ленинград. ун-та, 1987. С. 47.

10 Например; Lyons D. Constitutional Principles // 92 Boston University Law Review. 2012. P. 1242 ; Керимов Д.А., Чиркин В.Е. Политические институты и процессы. М. : ИГПАН, 1986. С. 128 ; Strahan R.M. A New Paradigm for Conservation of Great Whales in the Urban Sea of the United States Species in Need of a «Green Knight» // 36(2) Boston College Environmental Affairs Law Review. 2009. P. 473.
} 
Период советского социалистического устройства предлагал свой способ стимулирования разумной гражданственности. Например, Конституция СССР 1924 г. гарантировала возможность участия в управлении государством только представителям пролетариата. Только рабочие могли реализовать право на свободу слова или собрания. Кроме того, гарантией воспитания разумной гражданственности в советский период служила неоспоримая советская идеология. Преданность воспеваемому идеалу советского гражданина обеспечивалась авторитетом общественного мнения. Например, случаи использования нецензурной лексики разбирались на собраниях трудовых коллективов ${ }^{11}$. Такое следование высоким моральным стандартам, обеспеченное силой общественного мнения, является мощным стимулом к воспитанию разумной гражданственности. Тем не менее мы не можем однозначно утверждать, что современное российское общество отличается приверженностью стандартам нравственности и гражданственности. Скорее, обратный вывод о потере сближающего духа гражданственности, озвученный Президентом России в Посланиях Государственной Думе $^{12}$, обосновывает наличие официальной политики государства, нацеленной на воспитание патриотизма, гражданственности и толерантности среди молодежи и школьников $^{13}$. Здесь уместно упомянуть об оговорке Ю. Хабермаса, согласно которой социальное поведение едва ли может быть суммарным результатом индивидуального стратегического поведения, оно является скорее результатом обмена мнений в процессе общения с окружающими ${ }^{14}$.

Оспаривание «разумности» протестантов. Оспаривание «разумности» по-

11 Levitsky Serge L. Copyright, Defamation, and Privacy in Soviet Civil Law. 22 (1) Law in Eastern Europe. 1979. P. 120.

12 Например, Послание Президента России Владимира Путина Федеральному Собранию РФ // Российская газета. № 90. 27.04.2007.

13 Например, постановление Правительства РФ от 20.08.2013 № 718 «О федеральной целевой программе "Укрепление единства российской нации и этнокультурное развитие народов России (2014-2020 годы)"» // Собрание законодательства РФ. 2013. № 35. Ст. 4509 ; Указ Президента РФ от 19.12.2012 № 1666 «О Стратегии государственной национальной политики Российской Федерации на период до 2025 года» // Собрание законодательства РФ. 2012. № 52. Ст. 7477 ; Стратегия развития информационного общества в Российской Федерации (утв. Президентом РФ 07.02.2008 № Пр-212) // Российская газета. № 34. 16.02.2008.

$14 \quad$ Habermas Jurgen. Op. cit. P. 337. ведения протестантов может быть эфффективным предлогом для органов публичной власти, чтобы не допустить предполагаемой акции протеста, что может представлять собой опасность с точки зрения обеспечения политических прав человека. Разрабатывая правила «цивилизованного диалога» между государством и гражданами, авторы теорий совещательной демократии предполагают, что и государство должно проводить разумную политику учета общественного мнения. Утверждая, что все протестующие граждане мотивированы исключительно спровоцировать исполнительные органы, безосновательно оспаривая порядочность граждан, которые высказывают критику по отношению к органам публичной власти, государство тоже нарушает правила диалога с общественностью. Например, введение в 2012 г. запрета скрывать свое лицо, в том числе использовать маски и иные предметы, предназначенные для затруднения установления личности во время публичных мероприятий ${ }^{15}$, подразумевает, что государство воспринимает всех протестующих граждан как потенциальных нарушителей порядка, которых нужно видеть в лицо. Даже если среди граждан могут быть «экстремисты и провокаторы», право участвовать в управлении государственными делами, гарантированное ст. 32 Конституции РФ, предполагает, что государство обязано выслушивать мнения всех граждан, высказанные с соблюдением законных процедур, какими бы еретическими по своему содержанию эти мнения ни казались.

\section{Отсутствие злоупотребления правом как составляющая конструктивного протеста}

С точки зрения легитимности политических дискуссий важно, чтобы граждане не злоупотребляли своим правом на выражение протеста, продвигая интересы определенных «заказчиков» или провоцируя негативные реакции со стороны власти. В связи с этим в одном из своих публичных выступлений Владимир Путин подчеркнул важность права граждан публично протестовать против решений органов власти, но «в рамках, установленных

15 Федеральный закон от 08.06.2012 № 65-Ф3 (с изм. от 14.02.2013) «О внесении изменений в Кодекс Российской Федерации об административных правонарушениях и Федеральный закон "О собраниях, митингах, демонстрациях, шествиях и пикетированиях"». Ст. 2, п. 2 // Собрание законодательства РФ. 2012. № 24. Ст. 3082. 
законом» ${ }^{16}$. Соблюдение законных пределов это требование, которое граждане не всегда выполняют.

Формальные акты протеста, при которых граждане злоупотребляют своими политическими правами и свободами, отстаивая чужой интерес от своего имени, могут ввести в заблуждение других граждан. Российское право содержит определенные гарантии против злоупотребления правами на участие в выборах и референдумах. Например, Кодекс РФ об административных правонарушениях предусматривает ответственность граждан и должностных лиц за подкуп избирателей или участников референдума $^{17}$. Если же действия, связанные с подкупом избирателей, содержат признаки уголовно наказуемого деяния, то они преследуются в уголовном порядке, на основании ст. 141 Уголовного кодекса РФ ${ }^{18}$. Гарантии против злоупотребления правом при осуществлении других форм реализации протеста в действующем законодательстве отсутствуют. Тем не менее анализ практики российских судов, рассматривающих жалобы, например, на нарушение прав граждан на свободу слова, показывает, что судами уже установлены определенные стандарты привлечения к ответственности граждан и должностных лиц, которые подают жалобы или обращения в органы публичной власти с одной только целью - нанести вред другим гражданам. Если обращение в органы публичной власти продиктовано не намерением исполнить свой гражданский долг или защитить права и охраняемые законом интересы, а исключительно намерением причинить вред другому лицу, то такое лицо привлекается к гражданско-правовой ответ-

\footnotetext{
16 Путин: несогласные имеют право выражать свое мнение в рамках закона. Интервью Владимира Путина программе НТВ «Центральное телевидение» // РИА «Новости». 07.10.2012. URL: http://ria.ru/ society/20121007/768469265.html.

17 Кодекс РФ об административных правонарушениях от 30.12.2001 № 195-Ф3 (ред. от 30.09.2013). Ст. 5.16 «Подкуп избирателей, участников референдума либо осуществление в период избирательной кампании, кампании референдума благотворительной деятельности с нарушением законодательства о выборах и референдумах» // Собрание законодательства РФ. 2002. № 1 (ч. 1). CT. 1.

18 Уголовный кодекс РФ от 13.06.1996 № 63-Ф3 (ред. от 23.07.2013) (с изм. и доп., вступающими в силу с 01.09.2013). Ст. 141 «Воспрепятствование осуществлению избирательных прав или работе избирательных комиссий» // Собрание законодательства РФ. 1996. № 25. Ст. 2954.
}

ственности за злоупотребление правом (п. 1 и 2 ст. 10 Гражданского кодекса РФ) ${ }^{19}$.

\section{Необходимые характеристики конструктивного протеста}

Попытаемся теперь определить необходимые характеристики «разумного» протеста. Конструктивный протест нацелен не на эмоциональное выражение недовольства действиями органов публичной власти, а на конструктивный диалог, способный дать конкретные результаты. В нашем представлении конструктивный протест как механизм реализации права на участие в управлении государством должен отвечать следующим требованиям:

- протест должен затрагивать определенные вопросы, входящие в круг публичных дел ${ }^{20}$. В отличие от частных вопросов, публичные вопросы затрагивают интересы неограниченного круга лиц, зачастую имея прямое отношение к политике;

- $\quad$ протест должен быть направлен на достижение конечного результата - на выдвижение конкретного требования к органам публичной власти или же варианта решения конкретной публично-правовой проблемы. Такие неоспоримые, но при этом общие требования, как достижение мира во всем мире или предоставление укрытия каждому бездомному существу, тоже должны рассматриваться как выдвигаемые требования;

- требования граждан должны быть доведены до сведения органов публичной власти, например в рамках петиции, уведомления органов власти о проведении публичного мероприятия, открытого письма в СМИ и т.д. Это необходимо для того, чтобы органы публичной власти могли

19 Постановление Пленума Верховного Суда РФ от 24.02.2005 № 3 «О судебной практике по делам о защите чести и достоинства граждан, а также деловой репутации граждан и юридических лиц» // Бюллетень Верховного Суда РФ. 2005. № 4. Ст. 10.

20 Согласно Замечанию общего порядка номер 25 об участии в ведении государственных дел, изданному Комитетом ООН по правам человека, «ведение государственных дел представляет собой широкое понятие, связанное с осуществлением политических полномочий, в частности с реализацией законодательных, исполнительных и административных полномочий. Оно охватывает все аспекты государственного управления, а также разработку и осуществление политики на международном, национальном, региональном и местном уровнях» (Комитет ООН по правам человека. Замечание общего порядка 25. Пятьдесят седьмая сессия. 1996 г. Док. ООН. CCPR/C/21/Rev.1/Add.7). 
рассмотреть выдвигаемое требование и дать на него ответ;

- протест должен быть реализован в рамках законодательно регламентированных процедур. Важно, чтобы органы государственной власти могли принять необходимые меры по защите прав и интересов всех участвующих лиц;

- ни протестующие граждане, ни органы государственной власти не должны злоупотреблять своими правами и нарушать права и интересы других лиц. При этом мы рассматриваем только мирные акции, считая любые нарушения общественного и правового порядка в ходе выражения несогласия неконструктивными, неправомерными и преследуемыми по закону.

Повышение правовой культуры населения как средство стимулирования граждан к выражению конструктивного протеста

Реализация конструктивного протеста зависит и от правовой культуры населения. Так, С.А. Авакьян отмечает, что для эффеективной реализации Конституции РФ ее положения должны стать составной частью правосознания граждан ${ }^{21}$. Совершенствование правовой культуры граждан в целях надлежащей реализации их гражданско-политических прав это серьезная проблема, решение которой требует существенных мер, помимо принятия новых законов. Такой вывод следует, например, из толкования положений Международного пакта о гражданских и политических правах, изданного Комитетом ООН по правам человека в рамках Комментария общего порядка № 31. Комитет подчеркивает значение «образовательных и других подходящих мер» для исполнения государствами их обязательств в рамках Пакта22. Следовательно, правовые и административные меры, принимаемые в России в обеспечение права на участие в управлении делами государства, должны быть подкреплены иными мерами. К таким «иным» мерам относятся специальные предметы для школьников, раскрывающие понятия «гражданство», «патриотизм», «социализация», «толерантность» и т.д. Такие

21 Авакьян С.А. Демократия протестных отношений ... С. 3-17

22 Комитет ООН по правам человека. Замечание общего порядка № 31 о характере общего юридического обязательства, налагаемого на государства - участников Международного пакта о гражданских и политических правах. Док. ООН. HRI/GEN/1/Rev.9 (Vol. I). 2004 P. 308-314, par. 7. предметы играют важную роль в становлении гражданской позиции подрастающего поколения. Акцент государственной политики в области образования на гражданское воспитание личности был подержан Д. Медведевым, который в своем послании 2009 г. к Федеральному Собранию представил парламентариям идею проекта «Наша новая школа» ${ }^{23}$. Помимо прочих нововведений, прямо не относящихся к нашей теме исследования, предполагается скорректировать цели образования школьников, с тем чтобы стимулировать как индивидуальное личностное развитие, так и социальные навыки, позволяющие адаптироваться во взрослой жизни, сформулировать принципы собственной социальной идентичности и расставить долгосрочные жизненные приоритеты. В целях воспитания патриотизма и восстановления общего гражданского духа россиян в 2009 г. была принята и федеральная Концепция духовно-нравственного развития и воспитания личности и воспитания гражданина России ${ }^{24}$. Эта концепция обобщает систематический набор педагогических требований, следование которым способно обеспечить эффрективное решение многих социальных проблем.

\section{Заключение}

Анализ категории конструктивного протеста с точки зрения основных прав и свобод гражданина позволяет выделить его базовые характеристики. К таким характеристикам относятся: направленность на решение вопросов, входящих в круг публичных дел; нацеленность на достижение конечного результата; доведение до сведения органов публичной власти требований граждан; реализация в рамках законодательно регламентированных процедур; недопустимость злоупотребления правом.

Мы пришли к выводу о том, что санкции за нарушение процедуры выражения протеста не могут быть единственным средством, стимулирующим граждан к выражению конструктивного протеста. Задача повышения правовой культуры граждан - одна из наиболее важных на пути оптимизации диалога между государством и гражданским обществом.

23 Послание Президента России Дмитрия Медведева Федеральному Собранию // Российская газета. № 214. 13.11.2009.

24 Данилюк А.Я., Кондаков А.М., Тишков В.А. Концепция духовно-нравственного развития личности и воспитания гражданина России. М. : Просвещение, 2009. 


\section{Библиография:}

1. Варламова Н.В. Человеческий фрактор в развитии социалистического самоуправления народа // Политическая система: вопросы демократии и самоуправления. - М., 1988.

2. Клюев А.В. Политическая активность и формирование гармонично развитой, общественно активной личности. - Л., 1987.

3. Керимов Д.А., Чиркин В.Е. Политические институты и процессы. - М., 1986.

4. Данилюк А.Я. , Кондаков А.М., Тишков В.А. Концепция духовно-нравственного развития личности и воспитания гражданина России. - М., 2009.

5. Гуляихин В.Н. Правовая культура как объект научного исследования: методологические подходы, структура и критерии оценки // NB: Вопросы права и политики. - 2013. - № 4.

\section{References:}

1. Varlamova N.V. Chelovecheskii faktor v razvitii sotsialisticheskogo samoupravleniya naroda // Politicheskaya sistema: voprosy demokratii i samoupravleniya. - M, 1988.

2. Klyuev A.V. Politicheskaya aktivnost' i formirovanie garmonichno razvitoi, obshchestvenno aktivnoi lichnosti. - L., 1987.

3. Kerimov D.A., Chirkin V.E. Politicheskie instituty i protsessy. - M., 1986.

4. Danilyuk A.Ya., Kondakov A.M., Tishkov V.A. Kontseptsiya dukhovno-nravstvennogo razvitiya lichnosti i vospitaniya grazhdanina Rossii. - M., 2009.

5. Gulyaikhin V.N. Pravovaya kul'tura kak ob"ekt nauchnogo issledovaniya: metodologicheskie podkhody, struktura i kriterii otsenki // NB: Voprosy prava i politiki. - 2013. - № 4.

Статья поступила в редакцию 15 октября 2013 г. 